\title{
Dekonstruksi Citra Politik Jokowi dalam Media Sosial
}

\author{
Rusmulyadi $^{1}$ dan Hanny Hafiar ${ }^{2}$ \\ ${ }^{1}$ Universitas Islam Negeri Sunan Gunung Djati Bandung \\ ${ }^{2}$ Universitas Padjadjaran
}

\begin{abstract}
ABSTRAK
Proses pembentukan citra politik dapat terjadi dalam semua lini media, tidak terkecuali lewat media sosial. Media sosial telah banyak digunakan untuk mem-brading citra politik seseorang atau partai politik tertentu. Sebaliknya, media sosial ternyata juga digunakan sebagai media pertarungan simbolik untuk mendekonstuksi atau pun mendegradasi citra politik seseorang atau lembaga politik. Twitter merupakan salah satu jenis media sosial dengan karakter microblogging yang turut dimanfaatkan untuk mengkonstruksi dan juga mendekonstruksi citra politik. Penelitian ini dilakukan untuk menganalisa bagaimana citra politik mengalami dekonstruksi dalam ruang media sosial. Analisa penelitian diarahkan terhadap postingan Twitter dalam hastag \#2019Ganti Presiden. Sampel teks diambil dari tweet netizen yang ada dalam hashtag tersebut selama bulan April 2018. Hashhtag ini sendiri mengacu pada upaya untuk memviralkan pergantian Presiden dalam perhelatan Pilpres 2019. Penelitian ini menggunakan pendekatan kualitatif dengan metode analisa isi kualitatif. Penelitian ini dapat disebut sebagai penelitian analisa isi teks dengan aplikasi interpretasi hermeneutis terhadap teks Twitter yang dijadikan objek penelitian. Hasil penelitian memberikan gambaran bahwa dalam ruang media sosial citra politik Jokowi berupaya didekonstruksi dan dicitrakan sebagai sosok yang tidak kompeten, tidak memiliki kapabilitas sebagai pemimpin dan inkonsiten terhadap janji-janji politiknya. Berdasarkan hasil analisa dapat disimpulkan bahwa media sosial Twitter telah menjadi saluran bagi kontestasi dan perebutan citra politik. Tentu saja, di dalamnya ada proses kontruksi dan dekonstruksi.
\end{abstract}

Kata-kata Kunci: Citra politik; dekonstruksi; hermeneutika; media sosial; twitter

\section{Deconstruction of Jokowi's Political Image in Social Media}

\begin{abstract}
Process of political image establishment can occur in all media lines, instead social media. It had been using for branding the political image of someone or certain politic party. In another side, social media is also used as the symbolic of media fighting to deconstruct or degrade of political image of someone or politic institution. Twitter is one of social media with micro blogging character which is used to construct and also deconstruct the political image. This research has been working to analyze how the political image had deconstruction in social media. The analyzing of this research will go towards Ywitter posting in hashtag \#2019Change of president\#. Text sample took from the citizen of net nudge that in that hashtag on April 2018. It refers in the effort to viral the changing of president in President Selection event 2019. This research uses qualitative approach with qualitative content analyzes method. It is able to be called as qualitative content analyzes with hermeneutist interpretation towards Twitter text that as the research object. The result of research gives a description in social media of Jokowi political image that tries deconstructed and imaged as incompetent figure that does not have capability as a leader and inconsistent towards his politic commitment. Based on this analyses can be concluded that social media b Twitter ecome the way of contestation and seizure of political image. Indeed, there will be a construction and deconstruction process.
\end{abstract}

Keywords: Decontruction; heurmeneutics; political images; social media; twitter

Korespondensi: Rusmulyadi, S.Ag., M.Si., Program Studi Ilmu Komunikasi Fakultas Dakwah dan Komunikasi UIN Sunan Gunung Djati Bandung, Jl. A.H. Nasution No. 105 Cipadung Cibiru Bandung 40614, Email:rusmul@yahoo.co.id 


\section{PENDAHULUAN}

Kemenangan pasangan Jokowi-JK dalam Pilpres 2014 tidak bisa dilepaskan dari kerja dan aktivitas PR politik dalam mem-branding dan mencitrakan, terutama Jokowi, di semua lini media. Aktivitas PR politik ini menemukan momentum yang tepat, di saat konsolidasi demokrasi di Indonesia telah bergeser ke arah industrialisasi politik. Fase ini meniscayakan pentingnya variabel personal branding dan citra kandidat yang berkelindan dengan penguasaan media untuk mendekatkan sosok tokoh kepada publik sekaligus menaikkan pamor dan nilai jualnya dalam seleksi election. Kuatnya citra dan branding Jokowi pada perhelatan Pilpres 2014 menjadi variabel penting yang menghantarkan Jokowi menaiki tahta istana. Dalam sudut pandang personal branding, Jokowi dilekatkan sebagai sosok merakyat, membumi, rajin turun ke lapangan, ramah dan jujur. Posisi branding Jokowi ini dianggap sebagai ciri khas Jokowi yang unik dan berbeda dari sebagian besar brand pemimpin politik lainnya. Atau dengan kata lain dapat dibaca bahwa brand Jokowi memiliki diferensiasi yang tinggi dan keunggulan sebagai brand pemimpin politik (Salamah, 2015: 164).

Seturut dengan hal tersebut, konstruksi citra Jokowi yang direkam dalam konstruksi media massa secara massif juga menjadi bagian dari keunggulan elektoral Jokowi di
Pilpres 2014. Bahkan dapat dikatakan bahwa kemenangan Jokowi terletak pada kesuksesan dalam pembentukan citra di semua lini media. Kemelekatan Jokowi dengan media menjadikan Jokowi sebagai sosok kesayangan media (media darling). Kenyataan ini menjadi tontonan tersendiri dalam industri politik kontemporer di Indonesia. Meminjam konsep Guy Debord (dalam Putri, 2015: 3), Jokowi telah menjadi spectacle tersendiri dalam ruang media. Dalam tahap ini tontonan Jokowi menjadi komoditas media sekaligus menegaskan arti penting dari identifikasi semua kehidupan sosial dengan tampilan media. Bahkan proses produksi citra ini telah menggejala ketika sebelumnya Jokowi menjadi Gubernur DKI Jakarta. Jokowi dicitrakan dalam relung media sebagai tokoh yang merakyat dengan blusukannya, pejabat yang akrab dengan dunia anak muda karena referensi musiknya kepada musik rock dan metal serta pemimpin yang inovatif karena kebijakannya. Citra semacam inilah yang terus dikampanyekan tim sukses Jokowi dalam Pilpres 2014. Jokowi ditempatkan sebagai komunikator utama dalam strategi kampanye politik. Sebagai komunikator, Jokowi dinilai memiliki similarity dan humble yaitu rakyat Indonesia bila melihat dan mendengar cara bicara Jokowi yang sama dengan masyarakat pada umumnya dengan bahasa yang lebih informal dan merakyat. Kerendahan hati 
Jokowi sebagai komunikator tercermin dengan perilakunya yang tidak membatasi diri terhadap masyarakat. Komunikasi nonverbal Jokowi juga ditunjukkan dengan cara mencoba menempatkan diri setara dengan masyarakat lewat cara memandang, sentuhan, intonasi, dan gesture Jokowi (Damayanti \& Hamzah, 2017: 287).

Citra politik dan personal branding Jokowi yang terus disuarakan telah mencapai tingkat pengenalan atau popularitas yang tinggi. Citra dan branding ini selain dikenal luas, juga memiliki prototipikalitas yang tinggi. Prototipikalitas menunjukkan bahwa dibandingkan citra dan brand pemimpin politik lainnya, citra Jokowi dianggap mampu mewakili identitas sosial pemilih. Ia dianggap sebagai pemimpin prototip kelompok pemilih yang mewakili kelompok sosial pemilih. Ada kepercayaan yang tinggi selain keyakinan bahwa Jokowi mampu menjadi pemimpin yang adil, berpengaruh, karismatik dan populer tentunya (Salamah, 163). Tetapi persoalannya adalah kesuksesan mengkonstruksi citra dan branding politik juga bergantung kepada pemeliharaan citra politik dalam jangka waktu yang lama. Menurut Firmanzah (2007: 231), citra politik tidaklah selalu sama dengan dengan realitas empirisnya. Citra politik pada dirinya adalah upaya untuk membangun persepsi dan kesan publik terhadap suatu objek. Oleh karenanya citra politik mengandung di dalam dirinya imajinasi dan sangat mungkin berbeda dalam tataran objektifnya. Sebagai sebuah imajinasi tentu saja citra politik dapat dibentuk, dikonstruksi, dipertahankan bahkan diperkuat lewat aktivitas komunikasi politik. Pada titik ini, konstruksi citra politik yang terus diperbesar dan diperkuat turut memengaruhi opini publik. Pun sebaliknya, karena pada dasarnya citra politik sangat terkait dengan sistem kognitif masyarakat, citra politik juga dapat melemah dan luntur dalam ingatan publik.

Jadi dapat digarisbawahi bahwa citra politik bukanlah imajinasi yang menetap dan stabil dalam benak publik. Citra politik dapat bergeser dari satu bandul ke bandul lainnya. Penguatan citra politik membutuhkan strategi komunikasi politik yang tepat. Aktivitas komunikasi politik yang dilakukan juga harus dilakukan secara simultan dan kontinu. Ujung dari proses ini adalah tertanamnya citra politik yang positif sekaligus bisa mendorong publik untuk menjatuhkan pilihan politik. Tetapi dalam skala politik, citra politik akan mendapatkan uji kontestasi dan kompetisi dari kandidat dan partai politik lain yang juga melakukan aktivitas komunikasi dan kehumasan politik. Proses ini tentu saja membuthukan strategi PR politik yang tepat berikut kepiawaian dari praktisi PR dan konsultan politik. Sejalan dengan hal tersebut, kekuatan branding politik juga akan 
terus mendapatkan ujian dan tantangan. Dalam konteks citra dan branding politik Jokowi, Kalau selama ini tumpuan branding politik lebih banyak berada pada dimensi ketulusan (sincerity), dimana relasi sosial yang terbangun terlihat setara, karena citra yang coba dilekatkan adalah citra merakyat, membumi, ramah dan jujur, maka aspek lain dari citra politik Jokowi bisa menjadi pintu yang mendegradasi ketokohan Jokowi. Aspek kompetensi dan kharisma politik yang tidak terjaga dan terus dipropagandakan lawan politik akan menggerus citra dan brand politik Jokowi.

Disinilah sekali lagi keunikan dari kerja PR politik. Aktivitas PR politik tidak berada dalam situasi bebas kepentingan dan sepi kontestasi. Dalam kontestasi politik yang sengit, kerja PR politik harus mampu memenangkan dan menguasai persepsi dan opini publik. Persepsi positif yang terbentuk di benak publik tentu lahir dari citra positifmengenai tokoh politik tersebut. Dalam bahasa Walter Lipman (dalam Rahman, 2006), citra dijargonkan sebagai gambaran dalam pikiran, "picture in ourhead". Citra bermain-main dalam wilayah persepsi setiap orang. Citra merupakan gambaran tentang objek yang seringkali tidak berbanding lurus dengan realitas empirisnya. Disinilah letak penting PR politik, dimana kegiatan PR politik merujuk sebagai fungsi manajamen yang berorientasi pada tujuan politis sehingga citra kandidat politik menjadi sebuah keniscayaan dalam aktivitas PR Politik. Secara sederhana, Ardianto (2011: 62) merumuskan citra sebagai perasaan, gambaran diri publik terhadap perusahaan, organisasi atau lembaga, kesan yang dengan sengaja diciptakan dari suatu objek, orang atau organisasi. Definisi ini mengisyaratkan bahwa citra adalah segala sesuatu yang sengaja ditampilkan oleh organisasi atau lembaga untuk mendapatkan kesan positif dari publik. Oleh karenanya citra merupakan salah satu modal penting bagi organisasi dalam membangun opini publik. Opini publik yang terbentuk akan menggiring dan mendorong publik untuk bersikap partisipatif dan loyal terhadap langkah dan kebijakan organisasi.

Dalam konteks politik, Arifin (2003: 106) mendefinisikan citra sebagai gambaran publik tentang dunia politik. Dan karena pada dirinya politik adalah wilayah kontestasi, kompetisi dan konflik yang lahir karena perebutan kekuasaan, maka citra politik dapat bermakna gambaran dan persepsi publik tentang otoritas, kekuasaan, kewenangan, konsensus dan konflik yang memiliki makna tersendiri. Sebagai sebuah gambaran atau persepsi boleh jadi citra politik tidak berkorelasi dengan realitas objektifnya. Sebagai gugusan persepsi, terkandung di dalamnya kepercayaan, pengharapan dan nilai akan suatu objek, yang pada gilirannya akan diartikulasikan menjadi opini pribadi. 
Akumulasi opini yang terus bergulir dan berkelindan membentuk opini publik. Jadi secara tidak langsung memang citra politik diarahkan untuk membentuk opini publik tentang citra kandidat atau partai politik tertentu. Dalam pandangan Dan Nimmo (2006: 5-7), walaupun citra politik mengandung di dalam dirinya unsur subjektivitas yang ditandai dengan sikap, perasaan dan pikiran seseorang tentang objek politik tertentu, tetap saja citra politik memiliki kegunaan dan manfaat. Menurut Dan Nimmo setidaknya ada tiga manfaat citra politik, (1) pengetahuan politik seseorang betapapun sederhana dan sekalipun tidak lengkap dapat membantu seseorang dalam memahami peristiwa politik, (2) citra politik berguna dalam memberikan penilaian pada objek politik tertentu, atas dasar bahwa citra seseorang tentang politik memiliki korelasi dengan sikap, perasaan dan pilihan politiknya, dan (3) citra diri seseorang tentang politik bermanfaat dalam hal menghubungkan dirinya dengan orang lain. Lebih lanjut Dan Nimmo menjelaskan citra seseorang tentang politik akan membantu untuk mengidentifikasi gagasan atau peristiwa politik, memberikan pemahaman dan penilaian tentang objek atau situasi politik tertentu. Citra seseorang tentang politik juga dapat dijadikan basis penilaian mengapa sebuah peristiwa politik dapat diterima atau bahkan ditolak. Citra sekaligus menjadi penanda referensi politik seseorang sekaligus berfungsi sebagai alasan seseorang untuk menjalin relasi sosial dan politik dengan yang lainnya.

Tetapi yang perlu digarisbawahi adalah citra tentang politik bukanlah sesuatu yang menetap permanen dalam sistem kognitif seseorang, melainkan akan mengalami proses dinamisasi dan transformasi seiring dengan berubah dan bertambahnya pengetahuan dan pengalaman politik seseorang. Citra politik akan mengalami proses pertukaran dan penyesuaian seiring dengan ikhtiar masyarakat untuk mencapai konsensus dan penyelasaian masalah guna kepentingan yang lebih luas. Pada titik inilah, letak penting dari komunikasi dan sosialisasi politik. Sosialisasi politik yang dilakukan secara terus menerus akan menghasilkan citra politik dan pada gilirannya akan mendorong partisipasi politik. Menurut Arifin(2003), sosialisasi politik adalah bagian tidak terpisahkan dari komunikasi politik. Orientasi dasar dari proses komunikasi politik sendiri diarahkan untuk menciptakan dan memelihara citra politik yang positif dan sekaligus membentuk opini publik dengan caracara komunikasi yang lebih persuasif. Bagian dari proses komunikasi politik adalah aktivitas PR politik. Dalam pandangan Arifin, kerja-kerja PR politik berbeda dengan propaganda politik dan agitasi politik. PR politik melandaskan kerja politiknya dengan komunikasi yang lebih dialogis atau dua arah. Tetapi muara PR 
politik sebenarnya juga sama, yaitu berupaya membentuk, memperkuat dan memelihara citra politik. Pembentukan dan penguatan citra politik memerlukan kerja yang kontinu dan simultan. Perlu digarisbawahi bahwa kerja dan aktivitas PR politik tidak saja dilakukan saat hajat besar pemilihan umum, yang biasanya bertautan dengan proses kampanye politik, melainkan secara leluasa bisa dilakukan dalam momentum apapun dan kapanpun. Terlebih ketika proses demokrasi politik telah berubah menjadi industri politik, maka peran PR politik menjadi semakin strategis dan vital. PR politik bisa menjadi jembatan antara tokoh politik, partai politik dan publik. Walaupun dalam banyak hal McNair (1999: 128) lebih menekankan titik krusial aktivitas PR berlangsung selama proses kampanye politik. Menurut McNair, praktisi PR politik harus memiliki kekuatan dalam membentuk dan mengarahkan opini publik, dalam kaitannya dengan kandidat dan partai politik yang diperjuangkannya. Seorang PR politik diibaratkan seperti manajer sekaligus penulis kreatif dalam drama politik. Ia bertugas merancang dan mempublikasikan citra politik sekaligus menjadi pemberi masukan terhadap arah pembentukan opini publik.

Bisa disimpulkan bahwa tugas PR politik tidaklah mudah. Disamping harus memiliki kreativitas dalam menyusun pesan-pesan politik, membangun sebuah citra politik bukan hal yang instan dan sekali jadi. Faktor lain yang harus diperhitungkan juga adalah kompetitor politik. Lawan atau pesaing politik dapat mendekonstruksi dan mendegradasi usaha PR politik dalam menaikkan citra politik kandidat atau partai politik yang ditanganinya. Secara alamiah, dalam konstestasi politik masing-masing kepentingan politik berusaha menanamkan kesan positif kepada masyarakat. Kenyataan ini membuat banyak sekali citra yang harus direkam dalam benak publik, sehingga menyulitkan publik untuk mengingat citra apa yang hendak dibentuk dan diciptakan oleh suatu PR politik. Pada titik ini menurut Firmanzah (2007), PR politik harus memperhitungkan secara cermat latar sosial, budaya dan politik dari publik yang disasarnya. Karena faktor seperti agama, suku, latar pendidikan, kondisi geografis dan demografis bahkan usia juga turut memengaruhi respons publik terhadap citra politik. Selain itu, opini publik yang dimainkan oleh kompetitor politik dapat menggerogoti citra politik yang terlanjur di bangun PR politik. Gangguan (noise) sering muncul dalam artikulasi media mainstream ataupun media sosial. Ikhtiar ini ditambah bias persepsi dalam media massa juga dapat menjauhkan persepsi publik tentang citra yang dikehendaki PR politik. Pelemahan citra politik yang dimainkan lawan politik akan terus berlangsung selama proses politik terjadi. Karena sejatinya proses 
konstruksi dan dekonstruksi citra politik akan terus berlangsung selama aktivitas dan pergerakan politik ada. Proses konstruksi dan dekonstruksi politik akan selalu beriringan dengan proses pembentukan citra politik dan opini publik.

Bertolak dari kerangka tersebut, penelitian ini hendak menelusuri dan mengungkap bagaimana dekonstruksi citra politik dalam ruang media sosial. Fenomena kontemporer yang menarik untuk diamati adalah viralnya hastag \#2019GantiPresiden. Hashtag ini sendiri lahir sebagai perlawanan dari hashtag \#Jokowi2Periode. Perang hashtag dapat dibaca sebagai ikhtiar politik untuk membentuk dan menggiring opini publik. Dalam konteks ini, inheren di dalamnya adalah upaya-upaya untuk mendegradasi citra politik tertentu, dalam hal ini citra politik Presiden Jokowi. Destinasi akhir dari hal ini tentu saja adalah kemenangan dalam kontestasi dan kompetisi yang akan berlangsung dalam Pilpres 2019. Dalam politik kontemporer, media sosial telah menjadi sarana yang penting bagi kehidupan politik publik, khususnya generasi muda yang menjadikan media sosial sebagai tempat untuk mengkomsumsi berita, mengembangkan jati diri, dan identitas politik. Dazelan dan Vobic (dalam Gunawan, 2018) mengungkapkan bahwa perluasan media sosial telah berkontribusi pada modernisasi komunikasi politik yang signifikan sebagai sarana baru untuk memungkinkan komunikasi langsung dengan follower, dan memberikan pengaruh pada komunikasi pesan-pesan politik kepada pemilih. Menurut Ardianto (2011: 12) media jejaring sosial tidak hanya memiliki kekuatan sosial, politik, dan budaya, tetapi dari perspektif komunikasi berperan tidak hanya sebagai alat atau media komunikasi, tetapi membentuk publisitas, dan pencitraan individu dalam lembaga. Berdasarkan manfaat tersebut memungkinkan politisi untuk menggunakan media jejaring sosial untuk meningkatkan popularitasnya melalui media sosial selain untuk menyebarkan berbagai informasi mengenai kegiatan dan program kampanyenya. Kaplan dan Haenlein (dalam Haryanto, 2015: 85) mendefinisikan media sosial sebagai aplikasi berbasis internet yang dibangun dengan teknologi Web 2.0, dan memungkinkan pertukaran informasi. Menurut Kaplan dan Haenlein pula ada enam jenis media sosial: proyek kolaborasi (misalnya, Wikipedia), blog dan microblogs (misalnya, Twitter), komunitas konten (misalnya, Youtube), situs jaringan sosial (misalnya, Facebook), virtual game (misalnya world of warcraft), dan virtual sosial. Layanan media sosial sedikit demi sedikit mengalami sebuah kemajuan dalam layanan jejaring sosial, dengan kehadiran Twitter, layanan web 2.0 berjenis blogmikro dimana para penggunanya dibatasi hanya dapat menulis sebanyak 140 
karakter. Twitter dapat dengan bebas diakses baik dari pengguna maupun bukan pengguna. Keunggulan dari Twitter ini adalah sebuah kecepatan dalam menginformasikan sebuah informasi dan tentunya cepat dalam penerimaan.

Dengan hanya menggunakan batas 140 karakter Twitter menjadikan komunikasi pendek yang mengutamakan poin-poin utama dalam informasi tersebut. Walapun demikian, Twitter menjadi layanan yang baik dalam berkomunikasi, khususnya untuk berkomunikasi massa, karena dapat memberikan informasi dengan banyak orang tanpa membatasi orang dalam menerima informasi apa yang terdapat disana, yang perlu diperhatikan adalah siapa informan tersebut (Abraham, 2014: 69). Dalam politik kontemporer, Twitter merupakan salah satu media sosial yang leluasa untuk dijadikan saluran pesan-pesan politik adalah Twitter. Twitter banyak digunakan oleh para politisi dengan dukungan simpatisan maupun buzzer untuk penyebaran pesan politik dengan cara yang menarik perhatian, menyusun percakapan, dan membangun opini publik kemudian menjadi viral. Percakapan yang banyak dibahas di Twitter dapat menjadi trending topic, dan seringkali dijadikan sebagai sumber berita yang dikutip oleh media cetak maupun online. Dari sudut pandang PR politik, sebagai medium baru, Twitter telah menjadi saluran yang bebas untuk mengkonstruksi sekaligus mendekonstruksi citra politik tertentu. Penelitian ini akan mengungkap lebih jauh bagaimana dekonstruksi citra politik Jokowi terjadi dalam Twitter, terutama pada hashtag \#2019GantiPresiden.

Kajian tentang citra politik dan media sebenarnya telah banyak dilakukan beberapa peneliti sebelumnya. Pada umumnya penelitian dalam konteks ini banyak menggunakan pendekatan analisa isi media yang bercorak kualitatif. Penelitian yang langsung terkait dengan citra politik Jokowi dan media misalnya dilakukan oleh Nashirussolah, Diahloka dan Widodo (2014). Lewat penggunaan metode semiotika Roland Barthes dengan objek iklan politik "Jokowi Adalah Kita", didapat kesimpulan hasil penelitian yaitu citra politik Jokowi ditampilkan dan dikonstruksi sebagai seorang pemimpin muda yang mampu merangkul semua kalangan dan dicitrakan sebagai tokoh yang bisa memenuhi harapan dan cita-cita semua anak bangsa. Penelitian tentang representasi citra politik dalam iklan juga dilakukan oleh Ariviyanti dan Nurfebiaraning (2017). Dengan mendasarkan diri pada metode semiotika Charles Sanders Peirce, peneliti menganalisa citra politik Hary Tanoesoedibjo dalam iklan Perindo versi mars Perindo. Hasil peneltian menunjukkan bahwa Hary Tanoesoedibjo dalam iklan tersebut dikonstruksi sebagai tokoh politik yang kharismatik, peduli dengan rakyat kecil dan generasi penerus 
bangsa dan bisa memelihara pluralitas bangsa.

Penelitian analisa isi kualitiatif terkait dengan citra politik dalam media juga dilakukan oleh Yuniati dan Fardiah (2017) dan Putri, Cangara dan Sutan (2013). Penelitian Yuniati dan Fardiah mengolaborasi citra calon legislatif perempuan dalam pemberitaan media online. Objek media yang dianalisis dalam penelitian ini adalah Kompas.com dan Detik. com. Sedangkan metode analisa isi yang digunakan adalah framing model Robert $\mathrm{N}$. Entman. Hasil analisa terkait dengan citra caleg perempuan dalam kedua media online tersebut menunjukkan bahwa baik Kompas. com maupun Detik.com membingkai citra perempuan dalam politik dalam tiga kategori citra, yaitu citra fisik, citra populer dan citra konflik. Citra fisik yang dimaksud adalah bagaimana citra politik perempuan dibingkai hanya mengandalkan dimensi penampilan dan kecantikan fisik untuk meraih simpati pemilih. Sementara citra populer merujuk kepada citra politik perempuan yang dinilai seringkali bertumpu kepada aspek popularitas diri dalam kontestasi politik. Citra konflik sendiri merupakan kategori yang menunjukkan penggambaran citra politisi perempuan yang bersedia berkonflik untuk memenangkan pertarungan politik, termasuk di dalamnya upaya-upaya politik yang menghalalkan segala cara. Sebelumnya dengan sudut pandang yang hampir sama, penelitian Putri, Cangara dan Sutan juga berupaya menganalisa konstruksi citra politik selebriti dalam media. Penelitian ini memfokuskan diri pada postingan dalam blog Kompasiana dengan metode analisa isi yang digunakan adalah kerangka analisa wacana model Teun Van Dijk. Elaborasi hasil penelitian menghasilkan kesimpulan bahwa blogger Kompasiana dalam mengkonstruksi citra politik selebritas menggunakan ukuran citra subjektif dan citra objektif dalam menilai keterlibatan selebriti dalam perempuan. Peran liputan media juga dinilai peneliti berperan dalam pembentukan citra politik selebriti di kalangan Kompasioner.

Kajian yang dilakukan oleh peneliti sendiri memiliki kesamaan dengan penelitian sebelumnya dalam hal pendekatan analisa isi kualitatif untuk menguraikan dan menggambarkan citra politik dalam media. Aksentuasi perbedaan dengan penelitian sebelumnya adalah dalam hal penggunaan metode penelitian dan objek media yang dianalisa. Penelitian menggunakan metode analisa isi dengan bertopang pada kerangka kerja hermeneutika Paul Riceour. Sementara objek media yang dianalisa adalah postingan dalam Twitter, khususnya komentar netizen dalam hashtag \#2019GantiPresiden. Penelitian ini mengasumsikan bahwa dalam ruang media sosial citra tokoh politik secara bebas dan 
leluasa mengalami dekonstruksi atau pelemahan citra politik. Media sosial bisa menjadi saluran media dimana citra politik dikonstruksi dan didekonstruksi.

\section{METODE PENELITIAN}

Penelitian ini mengunakan pendekatan kualitatif dengan metode penelitian yang digunakan adalah analisa isi kualitatif yang bertumpu pada cara kerja hermeneutika. Pendekatan kualitatif menyiratkan penekanan pada proses dan makna yang tidak dikaji secara ketat atau tidak diukur secara kuantitatif. Penelitian kualitatif menekankan sifat realitas yang terbangun secara sosial, relasi subjektivitas antara peneliti dengan yang diteliti dan tekanan situasi yang membentuk penyelidikan dalam penelitian. Penelitian kualitatif mendasarkan pada proses penelitian yang sarat nilai. Peneliti kualitatif berupaya mencari jawaban atas persoalan-persoalan terkait pengalaman sosial dan makna suatu tindakan (Denzin \& Lincoln, 2009: 6). Sementara metode analisa isi kualitatif yang dimaksudkan dalam penelitian ini adalah analisa yang diarahkan untuk meneliti dokumen yang dapat berupa teks, gambar, simbol dan sebagainya. Dalam penelitian isi kualitatif, semua jenis dokumen atau data yang akan dianalisis disebut sebagai teks. Analisa teks dilakukan dalam kerangka memahami budaya dan konteks sosial yang melingkupi sebuah teks. Metode analisa isi kualitatif merujuk pada metode analisis yang integratif dan secara konseptual digunakan untuk menemukan, mengidentifikasi, mengolah dan menganalisa dokumen untuk memahami makna, signifikansi dan relevansinya (Ida dalam Bungin, 2001: 203).

Penelitian analisa isi kualitatif ini dilakukan terhadap postingan Twitter dalam hashtag \#2019Ganti Presiden. Sampel teks diambil dari tweet dan postingan yang ada dalam hashtag tersebut selama bulan April 2018. Hashtag ini sendiri mengacu pada upaya untuk memviralkan pergantian Presiden dalam perhelatan pemilu 2019. Analisa isi kualitatif terhadap hastag \#2019GantiPresiden juga bertopang pada interpretasi hermeneutis. Dengan kerangka interpretasi heremeneutis ini diharapakan bisa mengungkap keterkaitan antara teks dan konteks. Sehingga hasil analisa menghasilkan sebuah pembacaan yang utuh dan komprehensif terhadap persoalan yang dimaksud dalam penelitian. Penelitian ini menggunakan kerangka kerja hermeneutika Paul Ricoeur. Menurut Ricoeur (dalam Sastrapratedja, 2013: 6) hermeneutika merupakan penggalian makna melalui proses interpretasi. Intrerpretasi paling mendasar dilakukan terhadap teks atau bahasa dengan tujuan untuk direfleksikan. Untuk mencapai kedalaman makna sebuah teks, Ricoeur (dalam el Mahdi, 2007: 26-27) 
menyodorkan tiga tahap kerja hermeneutika. Pertama, level semantik, yaitu tahap dimana teks dipahami melalui struktur kata, kalimat dan makna yang terkandung di dalamnya. Kedua, level reflektif, yaitu teks kemudian direfleksikan dengan mengacu kepada dunia di luar teks. Ketiga, level eksistensial, yaitu tahap dimana refleksi terhadap teks dan dunia di luar teks dihubungkan dengan aktualisasi diri secara lebih filosofis (ontologis).

Dalam pandangan Thompson (1990: 408) interpretasi hermeneutik penting dan relevan dilakukan dalam ilmu sosial. Bahkan Thompson menyatakan penekanan mendasar pada proses memahami dan interpretasi memiliki nilai lebih hingga saat ini. Menyadarkan pada pemikir hermeneutika sebelumnya, Thompson menggarisbawahi bahwa studi tentang teks atau pun bentuk-bentuk simbol secara mendasar dan mutlak merupakan pemahaman dan interpretasi. Bentuk-bentuk simbol merupakan konstruksi makna yang harus diinterpretasikan. Simbol yang dimaksud dapat tindakan, ucapan ataupun teks tertulis. Kajian Thompson ini bertolak dari pemikiran hermeneutika Paul Ricoeur (dalam Thompson, 414). Lebih jauh Thompson menjelaskan gagasan yang mendasari hermeneutika adalah bahwa dalam penelitian sosial, proses interpretasi dapat dimediasi melalui metode eksplanatori dan “objektivikasi”. Metode ini dapat membongkar konstruksi dan relasi makna yang bersembunyi dalam sebuah teks. Eksplanasi dan interpretasi adalah bagian yang tidak terpisahkan dalam analisa hermeneutika.

Penelitian ini juga bertumpu pada konsep dekonstruksi. Dalam Kamus Besar Bahasa Indonesia (2008), kata dekonstruksi diterjemahkan sebagai penataan ulang. Mendekonstruksi berarti membongkar atau menata ulang. Dalam filsafat, dekonstruksi dihubungkan dengan pemikiran Jacques Derrida. Menurut Derrida (dalam Barker, 2014: 69-70), dekonstruksi lahir dari upaya membongkar narasi tentang struktur yang berlawanan dan bersifat hirarkis. Dalam strukturalisme, teks mengandaikan adanya posisi yang berhadapan, baku-tidak baku, pusat-marjinal, hitam-putih, lelaki-perempuan, akal sehat-kegilaan, dan sebagainya. Mendekonstruksi sebuah teks berarti menanggalkan oposisi dwikutub dan sekaligus menemukan dan menunjukkan asumsi-asumsi yang ada di belakang sebuah teks. Lebih jauh dinyatakan bahwa mendekonstruksi juga bermakna menganggap penting suarasuara atau teks yang terpinggirkan dari pusat kekuasaan.

Dalam pemikiran Derrida perbedaan antara pusat dan pinggiran merupakan konsekensi logis dari adanya struktur hierarkis dan relasi yang saling berhadapan. Pinggiran diasumsikan sebagai segala sesuatu yang berada pada 
batas, pada tepian, maupun di luar (outside), karena itu dianggap tidak penting. Sementara pusat adalah yang terdalam, pada jantung daya tarik dan makna dimana setiap gerakan berasal dan merupakan tujuan gerakan dari yang marjinal (Mantiri dan Makainas, 2011:

72). Dalam pemikiran Derrida, pandangan bahwa pusat adalah sesuatu yang superior dan agung, sementara marjinal adalah sesuatu yang inferior dan rendah harus ditolak. Bagi Derrida, opisisi semacam ini tidaklah adil dan harus disingkirkan, karena tidak ada posisi yang lebih unggul dan mengatasi yang lainnya. Singkatnya dalam pemikiran Derrida, dekonstruksi adalah kerja untuk menggeser dari pusat (sentral) ke pinggiran (marjinal). Dengan pemikiran ini, Derrida membuka peluang bagi pemikiran demokratis, dimana keragaman dan perbedaan dirayakan. Dekonstruksi Derrida merupakan perlawanan terhadap pemikran dan tindakan yang totaliter sekaligus membuka kemungkinan pemikiran berbeda untuk tampil secara terbuka.

Dalam konteks tulisan ini, pemikiran tentang dekonstruksi dapat diartikulasikan sebagai membongkar wacana (baca jug citra) yang telah dibentuk secara mapan oleh pusat kekuasaan dan pada saat yang sama mengkonstruksi ulang wacana baru (dan juga berarti citra baru) yang berbeda lewat gugusan teks. Dekonstruksi citra bermakna bias bermakna menjungkirbalikkan citra dan kebenaran yang diklaim pusat dengan cara menunjukkan kelemahan dan absurditas wacana dan citra yang terbangun. Tetapi yang perlu digarisbawahi sekali lagi bahwa mendekonstruksi wacana pada dirinya juga adalah ikhtiar untuk merekonstruksi dan menampilkan wacana yang lain dan berbeda.

\section{HASIL DAN PEMBAHASAN}

Sepanjang kekuasaannya, Jokowi dalam berbagai tampilan media mainstream dikonstruksi sebagai sosok pekerja dengan karakter sederhana. Setidaknya citra Jokowi ini dislogankan dalam frase "Kerja, Kerja, Kerja”. Simbolisasi citra kerja ini kemudian coba diperlihatkan dengan mega proyek pembangunan infrastruktur. Citra pekerja ini juga diterjemahkan dalam berbagai kegiatan blusukan yang menjadi citra khas Jokowi. Memasuki tahun politik, citra Jokowi juga ditambahkan dengan citra rasa Presiden milenial yang gaul. Hal ini setidaknya terlihat dari berbagai perilaku politik, seperti menonton film Dilan, touring coupper, dan lain-lain.Tentu saja karena citra politik tidak berada dalam ruang yang vakum, terlebih semakin intensifnya pergerakan politik menjelang pemilihan umum serentak Presiden dan anggota legislatif, maka upaya untuk mendegradasi dan mendekonstruksi citra politik dilakukan pihak-pihak yang tidak menginginkan Jokowi terpilih untuk periode kedua. Berbagai citra politik tandingan yang 
coba dibangun dan dilekatkan pada sosok Jokowi dalam media sosial setidaknya tertuang cuitan pada hashtag \#2019GantiPresiden.

Berbagai komentar dalam tagar \#2019GantiPresiden mengindikasikan adanya opini yang diarahkan untuk melemahkan citra politik Jokowi. Citra politik Jokowi didekonstruksi sebagai sosok yang tidak memiliki kompetensi sebagai Presiden. Kalau kompetensi didefinisikan secara sederhana sebagai kemampuan seseorang dalam bidang tertentu, maka citra politik Jokowi didekonstruksi sebagai sosok yang tidak memiliki kemampuan secara personal sebagai Presiden. Dari berbagai unggahan yang ada, citra politik Jokowi dikesankan sebagai Presiden yang tidak layak dan cakap. Citra politik Jokowi digambarkan sebagai Presiden yang tidak memiliki tampilan sebagai seorang Presiden. Kompetensi Jokowi sebagai Kepala Negara juga dinilai tidak mencerminkan sosok yang berwibawa dalam forum-forum internasional. Kompetensi berbahasa Inggris yang dinilai pas-pasan terutama ketika berbicara dalam forum-forum internasional yang penting juga dijadikan penanda sekaligus argumentasi Jokowi bukanlah sosok yang kompeten sebagai Presiden.Akun@fadree misalnya dengan nada nyinyir menuliskan komentar "Begini kok planga-plongo? Jokowi sangat piawai dalam menjawab!!cc@fadlizon@TsamaraDKI@psi_ id". Tweet ini dikaitkan dengan tautan video yang mempertontonkan cara menjawab Jokowi dalam forum ekonomi Internasional. Secara semantik komentar ini adalah rangkaian kalimat pejoratif yang mengandung satir terhadap kemampuan Jokowi. Dari susunan kalimat ini bisa direfleksikan adanya upaya penggambaran Jokowi sebagai sosok yang tidak kompeten, karena kurang piawai dan taktisnya dalam berkomunikasi dengan bahasa Inggris.

Kompetensi Jokowi sebagai Presiden juga didekontruksi dengan ketidakmampuannya dalam memberikan respons yang cermat dan terukur sebagai Presiden. Jokowi dikonstruksi sebagai sosok yang galau dan emosional. Narasi yang melandasi ini adalah pernyataan Jokowi dalam menanggapi maraknya kaos \#2019GantiPresiden. Pernyataan yang dimaksud adalah statement Jokowi "Sekarang isunya ganti lagi, isu kaus. \#GantiPresiden2019 pakai kaus. Masak kaus bisa ganti presiden? Yang bisa ganti presiden itu rakyat," Pernyataan ini dinilai sebagai ekspresi galau dan jauh dari kompeten. Dengan nada satir beberapa akun Twitter berkomentar tentang pernyataan Jokowi ini. Akun@unilubis misalnya menuliskan "Jokowi: masak pakai kaus \#GantiPresiden2019 bisa ganti Presiden. Ya memang gak ada jaminan. Lalu mengapa dibahas di pidato, Pak? \#galaudetected|". Begitu juga dengan akun@eae18 yang secara 
tegas menuliskan "Pernyataan-pernyataan Pak@jokowi ketika menanggapi isu-isu yang bertebaran, terlihat tak punya bobot sebagai presiden. Salah satu contohnya, pernyataan terkait kaos \#GantiPresiden2019. Ingin melucu tapi tak lucu. \#diBAPlagiDeh.”Dari analisa beberapa teks postingan tweet yang ada dalam hastag \#2019Ganti Presiden, gugusan kalimat komentar di atas mengandung kritik tajam terhadap respon komunikasi Jokowi. Makna yang dapat direfleksikan adalah upaya untuk mendekonstruksi citra politik Jokowi yang dipersepsikan selama ini sebagai pemimpin sederhana, humble dan dekat dengan rakyat. Kesan ini dalam saluran media sosial yang relatif bebas coba diruntuhkan dengan beberapa pelabelan yang mendistorsi citra politik Jokowi sebelumnya. Citra sederhana dikontraskan secara paradoksal dengan citra "planga plongo" dan tidak berwibawa. Citra pemimpin pekerja keras dan tulus dilawankan secara ironik dengan citra pemimpin emosional yang galau dengan ancaman ganti Presiden. Hasil analisa teks terhadap postingan yang ada pada hastag \#2019GantiPresiden juga berupaya mendekonstruksi citra politik Jokowi dalam hal kemampuannya memimpin negara. Jokowi dalam berbagai komentar yang ada pada tagar \#2019GantiPresiden juga didekonstruksi sebagai sosok yang tidak memiliki kapabilitas sebagai Presiden. Kapabilitas sering diartikan sebagai kemampuan dan keterampilan (skill) secara lengkap dalam menguasai dan mengatasi persoalan. Citra tidak capable ini coba ditunjukkan dengan beragam argumentasi dalam postingan Twitter. Jokowi didekonstruksi sebagai sosok yang tidak memiliki kemampuan mengatasi persoalan-persoalan kebangsaan. Salah satu bidang yang dianggap menjadi titik pelemahan dari citra Jokowi adalah ekonomi. Jokowi dinilai gagal oleh berbagai akun twitter dalam mengatasi persoalan pengangguran, daya beli masyarakat, mengendalikan kurs dan inflasi serta serbuan tenaga kerja asing ilegal.

Secara acak dari berbagai postingan yang ada dalam hashtag \#2019GantiPresiden meneguhkan konstruksi citra politik Jokowi yang tidak memiliki kapabilitas, terutama dalam mengatasi persoalan ekonomi. Akun @ fajarnoviartha misalnya mengeluhkan "Pokoknya ganti.. ampun.. listrik naik terus gak ngomong2.. \#GantiPresiden2019”. Ketidakmampuan Jokowi juga ditunjukkan dengan argumentasi kegagalan Jokowi dalam mengatasi nilai tukar rupiah yang merosot tajam terhadap dolar. Dengan menautkan pada link tentang kurs dollar, akun@Hasankancil1 memposting "Wow..meroket, benar kata beliau. . masih mau 2 periode? \#gantipresiden2019". Link yang dimaksud adalah skema fluktuasi nilai mata uang dimata Rupiah mengalami depresiasi. Secara semantik bisa dibaca pesan komunikasi 


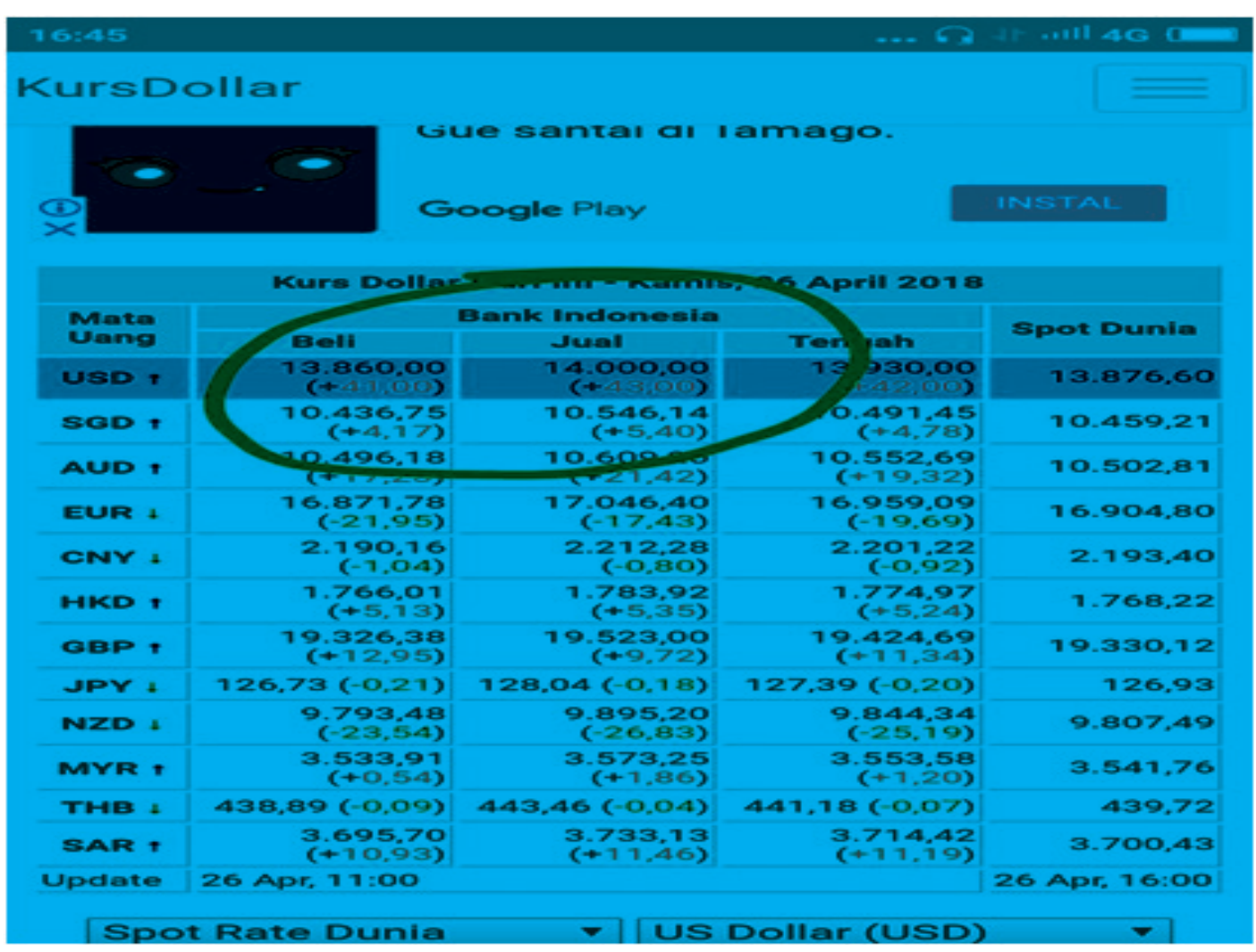

Sumber: Twitter, 2018

\section{Gambar 1 unggahan akun@Hasankancil1}

yang terkandung dalam postingan tersebut. kegagalan Jokowi untuk memenuhi janji Struktur kalimat dan bagan tersebut hendak politiknya di Pemilu 2014. Dalam perhelatan menandaskan ketidakmampuan Jokowi dalam mengatasi persoalan ekonomi. Refleksi lebih mendalam dari struktur narasi tersebut adalah adanya upaya netizen ini untuk melemahkan citra politik Jokowi dari citra pemimpin yang kredibel dan berhasil dalam beberapa jabatan sebelumnya, menjadi citra tokoh yang tidak kredibel dan tidak memiliki kapabilitas yang sebenarnya sebagai seorang pemimpin. Dengan tautan diagram di atas netizen@ Hasankancil1 seolah hendak mempertanyakan kapasitas Jokowi dalam memperbaiki persoalan ekonomi. Hal ini sekaligus hendak menegaskan Pilpres 2014, salah satu janji Jokowi yang banyak menjadi perhatian warga netizen dan publik pada umumnya adalah menurunkan nilai tukar rupiah hingga $10 \mathrm{ribu} / 1 \mathrm{USD}$.

Ketidakmampuan Jokowi dalam mengatasi persoalan ekonomi juga ditunjukkan dalam postingan@DiethaPutris. Dengan nada sarkas, akun ini memposting sebuah foto pencari kerja dengan capture "Susahnya nyari kerja di negri sendiri kalo nggak nyogok gk diterima Andai aku jadi imigran Cina pasti aku sudah diberikan pekerjaan oleh Jokowi dengan gaji 15 juta/ sebulan, Nyesel aku pilih Jokowi”. Kicauan ini 
berupaya mendekonstruksi citra politik Jokowi yang dinilai tidak mampu membuka lapangan pekerjaan dan mengatasi persoalan serbuan tenaga kerja asing illegal. Akun@DiethaPutris secara kritis memposting gambar dengan komentar yang sarkastis.

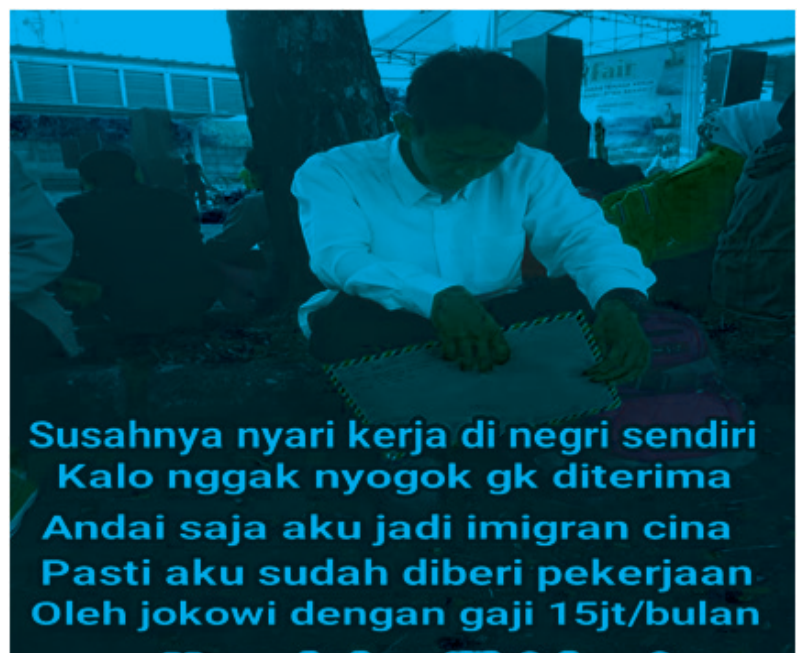

Sumber:twitter, 2018

\section{Gambar 2 akun@DiethaPutris, 2018}

Secara semantik, komentar dan gambar 2 menyiratkan pesan secara jelas tentang ketidakmampuan Jokowi dalam mengatasi persoalan ekonomi, terutama dalam hal penyedian lapangan pekerjaan. Refleksi dari hari tersebut, postingan ini berupaya mendekonstruksi citra politik Jokowi yang selama ini dipersepsikan sebagai pemimpin bangsa yang diyakini akan berhasil membawa kemajuan dan kemakmuran. Postingan ini sekaligus bisa dimaknai sebagai gugatan warga terhadap janji politik Jokowi yang berencana membuka lapangan kerja seluas-luasnya dan menurunkan angka pengangguran. Secara tidak langsung postingan jenis ini dapat dianggap sebagai bagian dari ikhtiar untuk membentuk dan menggiring opini publik terkait dengan citra politik Jokowi yang tidak memiliki kapabilitas sebagai pemimpin.

Dimensi lain dari citra politik Jokowi yang coba untuk diruntuhkan dan dilemahkan adalah citra konsistensi kepemimpinan Jokowi. Citra Jokowi didekonstruksi dan didegradasi oleh sebagaian warganet sebagai pemimpin yang tidak konsisten dengan janji politiknya. Secara tidak langsung, netizen berupaya menggerogoti dan memasuki dimensi moralitas seorang Pemimpin. Karena konsistensi sendiri seringkali dimaknai sebagai satunya kata dan perbuatan. Konstruksi inkonsistensi Jokowi itu ditunjukkan dalam beberapa postingan warganet dalam hashtag \#2019GantiPresiden. Inkonsistensi Jokowi dilandaskan pada bangunan narasi bahwa Jokowi tidak memiliki kepedulian terhadap rakyat kecil sebagaimana janji politiknya, Jokowi tidak setia dengan janji revolusi mental sebagai arah perjuangannya dan Jokowi tidak konsisten dalam menerapkan kebijakan.Narasi inkonsistensi Jokowi dalam hal keberpihakannya pada kelas pekerja disuarakan korban pemutusan hubungan kerja Freeport. Akun@HisarS1 memposting cuitan yaitu "8300 × 6 (suami istri, ortu dan mertua) dan di 
tambah dengan kakak beradik bersaudara dari 8300 \#korbanphksepihakfreeport mengatakan \#gantiPresiden2019 karena pemerintahan ini tidak peduli terhadap kami. Melupakan sumpah Pemerintahan ini". Secara semantik, susunan kalimat ini mengandung nada kekecewaan dan keputusasaan. Postingan ini secara reflektif berupaya menghubungkan antara moralitas politik dengan realitas empirisnya. Konsistensi moral Jokowi sebagai pemimpin yang dimanifestasikan dalam sumpahnya ternyata dinilai berbanding terbalik dengan keberpihakannya kepada kaum pekerja.

Inkonsistensi citra politik Jokowi juga dikumandangkan oleh warganet dengan akun @PP_Syariah. Akun ini dengan nada ironi mempertanyakan pelaksanaan gerakan revolusi mental yang dinilainya tidak konsisten. Lebih jauh akun ini menulis "Di 2019 saatnya revolusi mental.. bukan revolusi fisik, bangunan, tanah, jalan tol, naikin (listrik, bbm, harga sembako) dan saatnya merealisasikan janji politik yang belum terealisasi 1 pun. (fiksi kampanye 2019) \#gantipresiden2019 \#SiapUntukSelamat". Postingan secara semantik ini dapat dimaknai sebagai kritik atas jargon revolusi mental yang menjadi branding politik Jokowi. Lewat narasi teks yang paradoksal tersebut konsistensi Jokowi diuji. Dalam level reflektif, narasi ini bisa diposisikan sebagai langkah pembentukan dan penggiringan opini publik. Publik didorong untuk mempersepsi bahwa Jokowi adalah sosok pemimpin yang inkonsisten. Inkonsistensi citra politik Jokowi juga dikaitkan dengan penerapan kebijakan yang ambigu. Jokowi dikonstruksikan sebagai pemimpin politik yang tidak sejalan antara perkataan dan perbuatan. Penilaian ini setiadaknya disuarakan oleh akun @elfizal. Akun@elfizal seraya menautkan video pernyataan Jokowi terdahulu memposting sebuah tulisan "Huzzz..... Jangan liat Video ini Jadul: Saat Dirinya GUBDKI Tolak BLSM yg direncanakan SBY akibat kenaikan BBM LAAAA Sekarang juga tak setuju Makanya dilempar! Ok? Begitulah Negasikan semua Video Pakdhe maka kamu akan paham \#2019GantiPresiden.” Konteks pernyataan ini adalah ketika menjabat Gubernur DKI, Jokowi membangun citra diri sebagai pemimpin yang anti pada program Bantuan Langsug Tunai (BLT) yang dijalankan Presiden SBY. Tetapi saat menjadi Presiden, Jokowi dinilainya juga telah menerapkan kebijakan yang sama dengan format berbeda. Bahkan dengan nada nyinyir, netizen menyebutnya sebagai Bantuan Langsung Lempar(BLL). Hal ini merujuk pada video yang memperlihatkan Jokowi membagikan bantuan atau bingkisan yang dilempar langsung dari dalam mobil kepresidenan kepada masyarakat yang menunggunya. Postingan komentar dan tautan video netizen tersebut seacra semantik dapat dimaknai kritik terhadap seorang 
pemimpin yang dianggap tidak konsisten dalam bertutur dan berperilaku. Refleksi lebih luas tentang hal ini adalah gambaran tentang citra politik Jokowi yang tidak konsisten dalam penerapan kebijakan. Citra politik yang berupaya diruntuhkan oleh netizen adalah citra politik yang berkaitan langung dengan moralitas diri seorang pemimpin.

Dengan berpijak pada dimensi semantik dan reflektif secara sederhana dapat diformulakan tiga aspek citra yang berupaya dilekatkan dalam sosok Jokowi, yaitu citra tidak kompeten, citra tidak kapabel dan citra tidak konsisten. Citra tidak kompeten dihubungkan dengan ketidakcakapan berkomunikasi dalam forum internasional, tidak memiliki wibawa sebagai pemimpin negara dan dianggap terlalu reaktif dan emosional dalam merespons kritik. Citra tidak kapabel dihubungkan dengan ketidakmampuan Jokowi dalam mengatasi persoalan ekonomi, diantaranya yaitu merosotnya nilai tukar rupiah, inflasi yang tinggi, meningkatnya angka pengangguran dan sekaligus ketidaktersediaan lapangan kerja baru. Sedangkan citra tidak konsisten dibangun atas narasi pengingkaran janji kampanye politik Jokowi dalam hal keberpihakan kepada kaum pekerja dan yang tertindas, janji untuk melakukan revolusi mental dan inkonsistensi dalam hal tidak akan menerapkan kebijakan batuan langsung tunai.

Tabel 1 Citra Politik Jokowi dalam Hastag \#2019Ganti Presiden

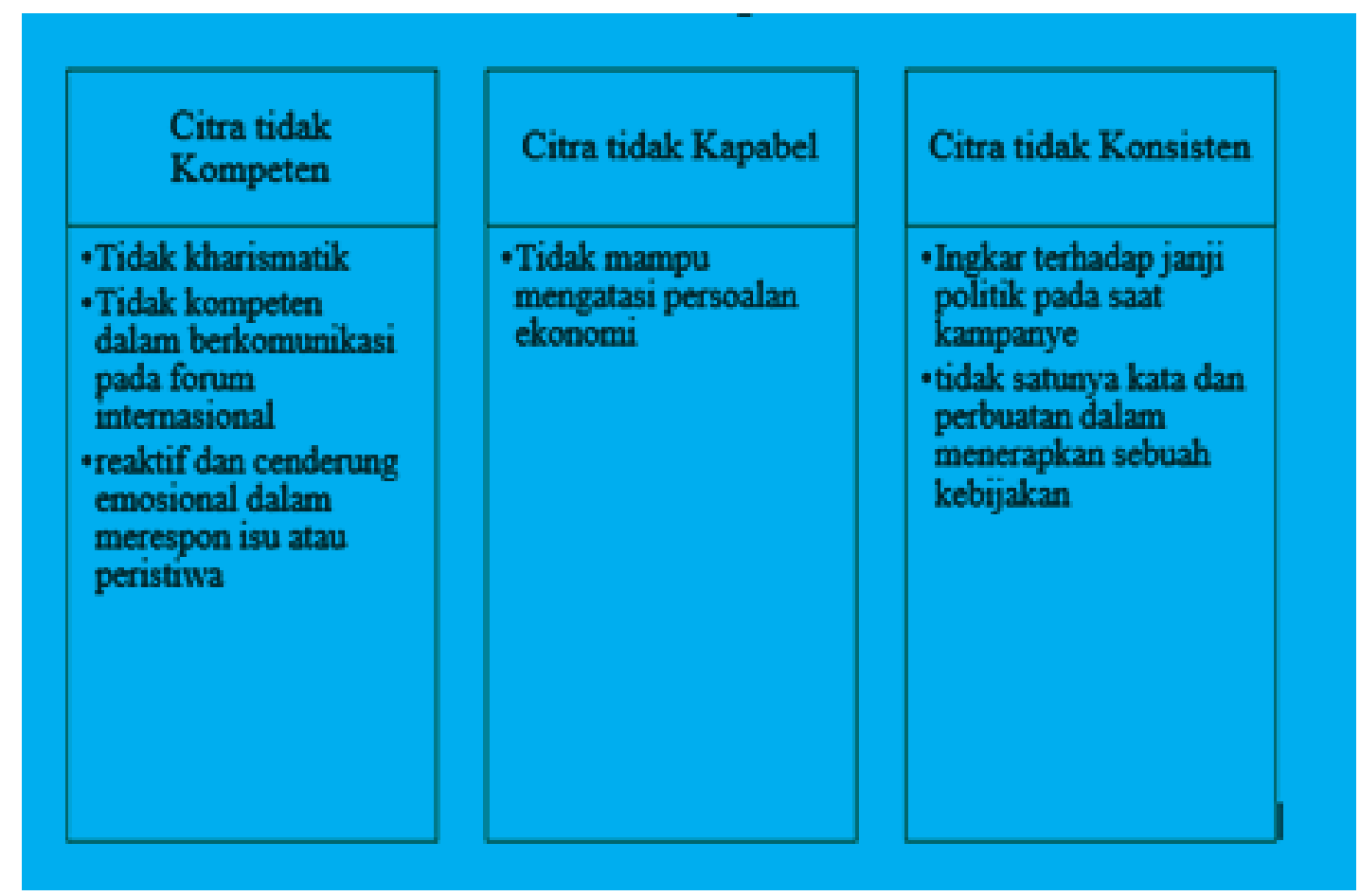

Sumber: Hasil Penelitian, 2018 
Pada akhirnya, secara eksistensial citra politik dipandang sebagai sebuah hasil konstruksi, dan pada saat yang sama karena citra politik tidak berada dalam ruang yang sepi kontestasi, citra politik juga akan mengalami proses antitesisnya, yaitu dekonstruksi atau pembongkaran citra. Proses ini sebuah keniscayaan, karena secara alamiah panggung politik adalah drama kontestasi, kompetisi dan seleksi. Pun demikian yang terjadi pada citra politik Jokowi dalam media sosial. Dalam konteks yang lebih filosofis, citra politik dalam media akan mengalami proses dialektika secara terus menerus seperti layaknya hukum tesis, antitesis dan sintesis. Dalam banyak media mainstream misalnya, Jokowi dikonstruksi sebagai pemimpin sederhana, merakyat, berorientasi kerja dan bersih dari korupsi. Bangunan citra politik seperti ini tentu saja akan mengalami uji dialektika. Karena citra juga lebih banyak bermain pada wilayah simbol dan persepsi. Maka akan selalu ada upaya untuk melakukan anti tesis terhadap citra politik yang dibentuk. Proses antitesis ini bisa dimaknai sebagai sebuah dekonstruksi atas citra politik yang dibangun. Analisa semantik dan reflektif terhadap aneka komentar netizen dalam hashtag \#2019GantiPresiden menunjukkan adanya upaya untuk membuat antitesis terhadap citra politik yang hampir sudah menjadi branding Jokowi selama ini. Jokowi kemudian dicitrakan sebagai pemimpin yang tidak kompeten, tidak kapabel dan tidak konsisten. Dalam ruang media yang seperti tak bertuan, citra politik Jokowi mengalami ujian dan tantangan. Oleh karenanya penguatan dan pemantapan citra politik Jokowi juga akan sangat bergantung pada strategi dan rancangan untuk memenangkan persepsi dan suara publik dalam dunia maya. Pada titik inilah dibutuhkan kerja-kerja PR politik yang taktis dan efektif dalam merebut opini publik di media sosial.

\section{SIMPULAN}

Fenomena kontemporer politik Indonesia memang tidak bisa dilepaskan dari gema dan kumandang suara warga netizen. Media sosial di Indonesia, termasuk di dalamnya Twitter, menjadi saluran yang relatif bebas dalam mengelola dan menyebarluaskan pandangan dan informasi politik. Media sosial seakan menjadi kanal perebutan dan pertarungan pesan-pesan politik. Inheren didalamnya adalah upaya untuk mengkonstruksi dan mendekonstruksi citra politik sosok dan partai politik tertentu. Dalam perspektif politik, dekonstruksi citra politik bisa saja dimaknai sebagai propaganda, dan Twitter merupakan ruang terbuka bagi para politisi dengan dukungan simpatisan maupun buzzer untuk penyebaran pesan dengan cara yang menarik perhatian, menyusun percakapan, dan membangun opini publik kemudian menjadi 
viral dan trending topic.

Tetapi yang perlu ditekankan pula bahwa ekspresi dan artikulasi dalam media sosial juga bisa dibaca sebagai media perlawanan kelompok marjinal terhadap pusat kekuasaan. Artikulasi perlawanan ini dilakukan lewat teks dengan cara mendekonstruksi dan mendegradasi citra politik sosok dan parpol tertentu. Hashtag \#2019GantiPresiden yang menjadi viral dan trending topic bisa dimaknai dalam kerangka ini. Beberapa postingan netizen dengan tagar tersebut mendekonstruksi citra politik Jokowi sebagai sosok yang tidak kompeten, tidak memiliki kapabilitas sebagai pemimpin dan inkonsiten terhadap janji-janji politiknya. Dengan kata lain dapat disimpulkan bahwa dalam ruang media sosial, upaya dekonstruksi citra politik yang dilakukan warga netizen merupakan sebuah keniscayaan yang terjadi, dan keteguhan sebuah citra politik akan terus mengalami ujian dalam ruang-ruang publik.

Hashtag dan gerakan \#2019GantiPresiden dengan segenap wacana tandingannya juga akan mengalami fluktuasi atau bahkan resonansi. Wacana ini akan menguat jika konstruksi dan argumentasi yang dibangun berbanding lurus dengan realitas objektifnya. Gerakan ini akan menguat seiring dengan momentum yang tepat dan bersesuaian dengan perasaan, persepsi dan sikap masyarakat. Dan pada saat yang sama, PR dan konsultan politik Jokowi juga harus secara simultan dan kontinu menghadirkan fakta dan data bahwa tidak ada kesenjangan antara citra politik Jokowi dengan pencapaian kinerjanya.

\section{DAFTAR PUSTAKA}

Abraham, F. (2014). Pemanfaatan twitter sebagai media komunikasi massa. Jurnal Penelitian Pers dan Komunikasi Pembangunan, Vol. 18 No.1

Ardianto, E. (2011). Handbook of public relations. Bandung: Simbiosa Rekatama Media.

Arifin, A. (2003). Komunikasi politik; paradigma, teori, aplikasi, strategi \&komunikasi politik indonesia. Jakarta: Balai Pustaka.

Ariviyanti, B.C. \& Nurfebiaraning, S. (2017). Analisis aktivitas pembenttukan citra politik hary tanoesoedibjo. Jurnal Channel, Volume 5, Nomor 1

Barker, C. (2014). Kamus kajian budaya. Jakarta: Kanisius.

Bungin, B. (2001). Metodologi penelitian kualitatif. Jakarta: RajaGrafindo Persada.

Damayanti, N. \& Hamzah, R. E. (2017). Strategi kampanye politik pasangan jokowi-jk pada pemilihan presiden 2014. Jurnal WACANA. Volume 16 No. 2.

Denzin, N. K. \& Lincoln, Y. S.(2009). Handbook of qualitative research. Yogyakarta: PustakaPelajar.

El Mahdi, L. I. (2007). Hermeneutikafenomenologi paul ricouer: dari pembacaansimbol hingga pembacaan teksaksi-sejarah. Hermenia Jurnal Kajian Islam Interdisipliner. Volume 6, Nomor 1.

Pusat Bahasa Departemen Pendidikan Nasional. (2008). Kamus bahasa indonesia. Jakarta: Pusat Bahasa. 
Firmanzah. (2007). Marketing politik; antara pemahaman dan realitas. Jakarta: Yayasan Pustaka Obor Indonesia.

Gunawan, B. (2018). Propaganda politik melalui 'hashtag' media sosial, dalam kolom detikNews, diakses pada tanggal 8 Mei 2018 pukul 07.37 WIB.

Haryanto. (2016). Pemanfaatan social media network sebagai media komunikasi komunitas pustakawan homogen dalam rangka optimalisasi resources sharing koleksi antar perguruan tinggi. Jurnal Pustakaloka.Volume 8 No.1.

Mantiri, H. J.\& Makainas, I. (2011). Eksplorasi terhadap arsitektur dekonstruksi. Jurnal Matrasain. Volume 8, Nomor 2.

McNair, B. (1999). Introduction political communication. London: Routledge.

Nashirussolah, D. C. W. \& Herru, P. ( 2014). Analisa semiotika pencitraan jokowi, JISIP: Jurnal Ilmu Sosial dan Ilmu Politik. Volume 3, Nomor 2.
Nimmo, D. (2006). Komunikasi politik; khalayak dan efek. Bandung: Remaja Rosdakarya.

Rahman, A. A. (2006). Citra khalayak tentang golkar. Jakarta: PSAP.

Salamah, U. (2015). Brand pemimpin politik. Jakarta: Makna Informasi.

Putri, C. D. Cangara, H. \& Sultan, I. (2013). Pencitraan selebritas politisi di blog kompasiana. Jurnal Komunikasi Kareba. Volume 2, Nomor 2.

Putri, S. A. R. (2015). Media dalam perspektif tontonan: jokowi spectacle. Jurnal The Messenger, Volume VII, Nomor 1.

Sastrapratedja, M. (2012). Hermeneutika dan etika naratif menurut paul ricoeur. Jurnal Kanz Philosophia. Volume 2, Nomor 2.

Yuniati, Y. \& Fardiah, D. (2017). Citra caleg perempuan dalam 'framing' $\mathrm{m}$ e d i a 'online'. Jurnal Mediator. Volume 10, Nomor 1. 